\title{
The Innovation of Standard Attitude Assessment Instrument for The Indonesian 2013 Curriculum
}

\author{
Amrullah $^{1}$, Arifuddin Arifuddin ${ }^{1, *} \&$ Nawawi $^{1}$ \\ ${ }^{1}$ Universitas Mataram, Indonesia \\ *Corresponding author: Universitas Mataram, Indonesia. E-mail: arifpgn@yahoo.com
}

Received: April 13, 2019 Accepted: July 8, 2019 Published: August 20, 2019

doi:10.5296/ije.v11i3.14658ＵRL: https://doi.org/10.5296/ije.v11i3.14658

\begin{abstract}
There is no standard manual of attitude assessment. The present study aimed at exploring the attitude aspects, teachers' understanding, reasons for choosing instruments, obstacles in the implementation, and efforts to overcome difficulties in the attitude assessment. This is formative research and development. It shows that the aspects of attitude appropriate with Indonesian 2013 Curriculum involve honesty, responsibility, tolerance, discipline, cooperation, peace, and politeness; teachers' perception of attitude assessment is Fairly Positive; teachers' understanding of the attitude assessment is Fairly Good; the dominant instruments are observation and interview; the reasons for instruments choice are based on the appropriateness, practicality, and effectiveness; obstacles in the implementation of attitude assessment relate to the time span, broad coverage of attitude aspects, continuous assessment, lack of conceptual understanding, variability of format, difficulties in assessing certain attitude aspects; teachers efforts to overcome problems in the implementation of attitude assessment involve assigning group tasks, discussion with peer teachers, providing special guidance, intensifying interactions with the students and their parents, giving rewards and enhancing students motivation.
\end{abstract}

Keywords: Attitude, Assessment, Perception, Instrument, Curriculum 


\section{Introduction}

The idea of conducting the present study is motivated by the fading of socio-cultural values, noble character, and identity of the younger generation, even though the Indonesian nation was built with a heritage of noble cultural values. One of the urgent values to be preserved is integrity or honesty. Lately, the portraits of national generations have been contaminated by dishonesty, which would be considered the national identity. There is an assumption that honesty is a rare and very expensive thing in Indonesia. Imagine, for example, how much the 'money' of the people is used up and how much time is taken to oversee the National Examination activities every year?

A worry related to the National Examination also emerged from the Indonesian Minister of Education and Culture Anies Baswedan. Even, he brought the phenomenon to the implementation of the National Examination to the Corruption Eradication Commission because there was allegedly massive national dishonesty in the implementation of the National Examination. The objectivity of the attitude assessment on the semester exam or other examinations at school is also questionable. There is a possibility that the growth of fertility culture is dishonest and the practices of Corruption, Collusion and Nepotism in learning evaluation. Such social diseases have been one of the triggers for the destruction of the nation's generation through educational institutions. If ignored, subjectiveness is likely to become a culture or identity of the Indonesian nation. Meanwhile, soon Indonesia will enter the global world that demands openness, honesty, objectivity and freedom from Corruption, Collution, and Nepotism. One of the most effective solutions is to overcome social problems involving the learning evaluation in the world of education.

The worry of the Minister and other people, including the educational observers and practitioners is quite reasonable. Although most Indonesian people realize that being a noble human being becomes one of their dreams, there are still many Indonesian people who are less determined to practice moral values, even to commit corruption. Unfortunately, according to the 2015 corruption index report, Indonesia is at the 88th most corrupt country in the world. It is a 'disaster' if the actors of corruption are educators and education practitioners. Who will be eligible for the role model in the effort to preserve the integrity and national identity?

One of the government's efforts in national character building and preservation of cultural values is to place the affective domain at the top of the education competency target hierarchy in the Indonesian 2013 Curriculum (thereafter C-13). Because it is relatively new, in its implementation there are still some problems. These problems are related to the lack of understanding of the teachers, the unclear scope of the assessment aspects and the technical implementation of the attitude assessment. The results of the Monitoring and Evaluation of the C-13 Implementation in West Nusa Tenggara Province organized by the Directorate of Learning and Student Affairs of the Directorate General of Higher Education at the Ministry of National Education with University of Mataram in 2014 showed that teachers' understanding of authentic assessment and attitude assessment was only in the category of 'medium'. The teachers are incompetent in carrying out and 'executing' the results of the 
attitude assessment objectively. Therefore, it needs assistance or training using innovative instruments. Several other studies also show relatively similar results, for example, Sunarpi, et al. (2015), Suharji (2014), Setyowati, Siswandari, Octoria (2014), Absari, et al. (2015), Ningsih (2012), Rosalinda (2016), Rusilowati (2013), Rahmawati (2015). At the same time, the teachers were forced to include attitudes on student rapport; whereas, assessing attitudes requires precision, objectivity, and high integrity. These three elements are difficult to get from some Indonesian educators. In short, educators agree that attitude or affective variables are important for learning (Agih, 2017). However, the affective assessment is often overlooked in educational assessment (Gerlaugh et al., 2007; Saxon et al., 2008).

The primary problem is that the instruments used in try-out of the $\mathrm{C}-13$ have not been standardized, that is, they have not been innovated based on needs analysis, both from the makers' and users' perspectives. We hope that the description of attitudes, character and national culture will be reflected and based on the results of an accountable attitude assessment.

Because there is no standard instrument, including the Standard Operating Procedure, until now there is no procedure for the teachers to follow in assessing student attitudes. Accordingly, the efforts to preserve cultural values as one of the $\mathrm{C}-13$ orientations, namely the cultivation of moral values, attitudes, noble character, and national identity through the world of education are very relevant to the strategic priority areas of Social Humanities Cultural Arts - Education directed on building and fostering national character. This focus area is one of the targets of developmental research that is used to test or develop concepts, models, or propositions so that they can be useful for solving problems in the community or social life.

One of the most prominent problems is the teacher's low understanding of the authentic assessment and attitude assessment. The teachers do not yet have sufficient competence in carrying out and 'executing' the results of the attitude assessment objectively. This research and development activities will produce an innovative Attitude Assessment Instrument that will be used nationally. The instrument is a reference for the assessment of objective attitudes. So, this study is very useful for the availability of honest and objective teachers in assessing learning outcomes, and have high integrity, who are free from social problems in the world of education. Thus, teachers will be ready to face the challenges of a globally transparent and accountable world. In addition, the output of this research is in the form of a textbook on innovative attitude assessment.

Thus, this research and development activities aim to: 1) Identify the aspects of attitude assessment; 2) Measuring the teacher's understanding of the components and procedures of attitude assessment; 3) Determine the teachers' perception of the attitude assessment; 4) Knowing the attitude assessment procedures that the teachers applied; 5) Exploring the obstacles experienced by the teachers in determining the attitudinal values; and 6) Knowing the efforts made by the teachers in overcoming the problems or difficulties in attitude assessment.

This research and development activities will produce an innovative Attitude Assessment 
Instrument that will be used nationally. The instrument is a reference for the assessment of objective attitudes. So, this study is very useful for the availability of honest and objective teachers in assessing learning outcomes, and have high integrity, who are free from social problems in the world of education. Thus, teachers will be ready to face the challenges of a globally transparent and accountable world. In addition, the output of this research is in the form of a textbook on innovative attitude assessment.

Research conducted by Suharji (2014), Setyowati, Siswandari, Octoria (2014), Absari, et al. (2015), Ningsih (2012), Rosalinda (2016), Rusilowati (2013), and Rahmawati (2015), and Arifuddin (2015) only focused on the lack of understanding and difficulties of teachers in making rubrics and the application of authentic assessments in general; while the proposed research focuses more on the identification of attitude aspects as a reference for attitude assessment; measuring teacher understanding of the components and procedures of attitude assessment; exploring the obstacles to determining the attitude values; and design and innovation of the Attitude Assessment Instrument. That is the novelty of the present study. More importantly, the contribution of the present study is the availability of innovative, standard, objective Attitude Assessment Instruments as a breakthrough in learning technology. In addition, affective learning has suffered from benign neglect, wherein faculty have failed to identify and describe their legitimate aims for students' affective learning (Colby \& Sullivan, 2009).

The output of this study will provide a very prospective contribution to the preservation of noble values in an effort to realize an objective Indonesian society, have a commendable character, and have high integrity through educational institutions. In other words, this research and development activities have an 'urgency', that is, an effort to preserve cultural values, character, noble character and national integrity reflected in the life and measured through accountable attitudes as reinforcement of national innovation systems in the success of $\mathrm{C}-13$. To achieve this goal, this research and development activities which can produce (output) in the form of innovative and standard Attitude Assessment Instruments that will be used nationally are very urgent to do. It is expected that the Indonesian nation will return to having a commendable identity and free from social problems in the world of education relevant to one of the $\mathrm{C}-13$ missions. So, from various perspectives, this research is absolutely urgent to do.

\section{Review of Literature}

Attitude is a predisposition learned to respond negatively or positively to an object, concept, person, event or situation. There are four types of critical affective characteristics proposed by Mardapi, namely attitudes, interests, values, and self-concepts (Mardapi, 2012). Attitudes and values cannot be assessed in the same ways as physical behaviors. The affective domain could be about learners being engaged with the development and understanding of their own motivations, attitudes, values and feelings with respect to behavior as a citizen and a professional (Birbeck, 2009). For example, students demonstrate "valuing" when they consistently prioritize time effectively to meet academic obligations and when they, for 
example, practice the safe handling of equipment and materials in a laboratory science course throughout a semester (Gronlund \& Brookhart, 2009).

With regard to learning, there are 18 kinds of affective that must be measured during the teaching and learning process, e.g. religious, honesty, responsible, discipline, hard work, self confidence, logical thinking, critical thinking, creative, innovative, independent, curiosity, love knowledge, respect, polite, democracy, emotional intelligence, and pluralist (Elfindri, 2012; Lickona, 2012; Koesoema, 2012; Mustari, 2014).

Why is assessing attitude in learning important? Petrosyan et al. (2005) state that students attitudes toward learning play major role in how much learning those students subsequently pursue. Besides, Keblowska (2012) argues that attitude, as a component of affective skills, has the important role in learning, e.g. learning a foreign language. According to research that has been done by Hambali (2015), it is important for teachers to assess the students' affective skills, e.g. attitude, continuously and frequently.

In Indonesian context, as indicated by the results of the preliminary study in the form of Monitoring and Evaluation of C-13 Implementation in West Nusa Tenggara Province (Sunarpi, et al., 2014), there were very serious problems related to the implementation of $\mathrm{C}-13$. One of the most prominent problems is the teacher's low understanding of the authentic assessment and attitude assessment. The teachers do not yet have sufficient competence in carrying out and 'executing' the results of the attitude assessment objectively.

In addition, based on the results of monitoring and evaluation related to the implementation of Curriculum 2013 at Junior High School in 2014 that was conducted by the Directorate of Junior High School Development, it indicates that one of the teachers' difficulties in implementing the Curriculum 2013 was in carrying out the assessment (Ministry of Education and Culture, 2015). Besides, it was found that more than $50 \%$ of teachers stated that they have not been able to design, implement, and process the assessment results properly. They added that the main difficulties are in formulating the indicators of assessment, compiling instrument items and carrying out an affective assessment with various techniques. So, recently, it becomes the main issue in education field.

Furthermore, based on the results of monitoring and evaluation related to the implementation of Curriculum 2013 at Junior High School in 2014 that was conducted by the Directorate of Junior High School Development, it indicates that one of the teachers' difficulties in implementing the Curriculum 2013 was in carrying out the assessment (Ministry of Education and Culture, 2015). Besides, it was found that more than $50 \%$ of teachers stated that they have not been able to design, implement, and process the assessment results properly. They added that the main difficulties are in formulating the indicators of assessment, compiling instrument items and carrying out an affective assessment with various techniques. So, recently, it becomes the main issue in education field. 


\section{Macrothink}

\section{Methods}

\subsection{Design}

Based on the State of the Art of this study, this is formative research and development (Tessmer, 1998).

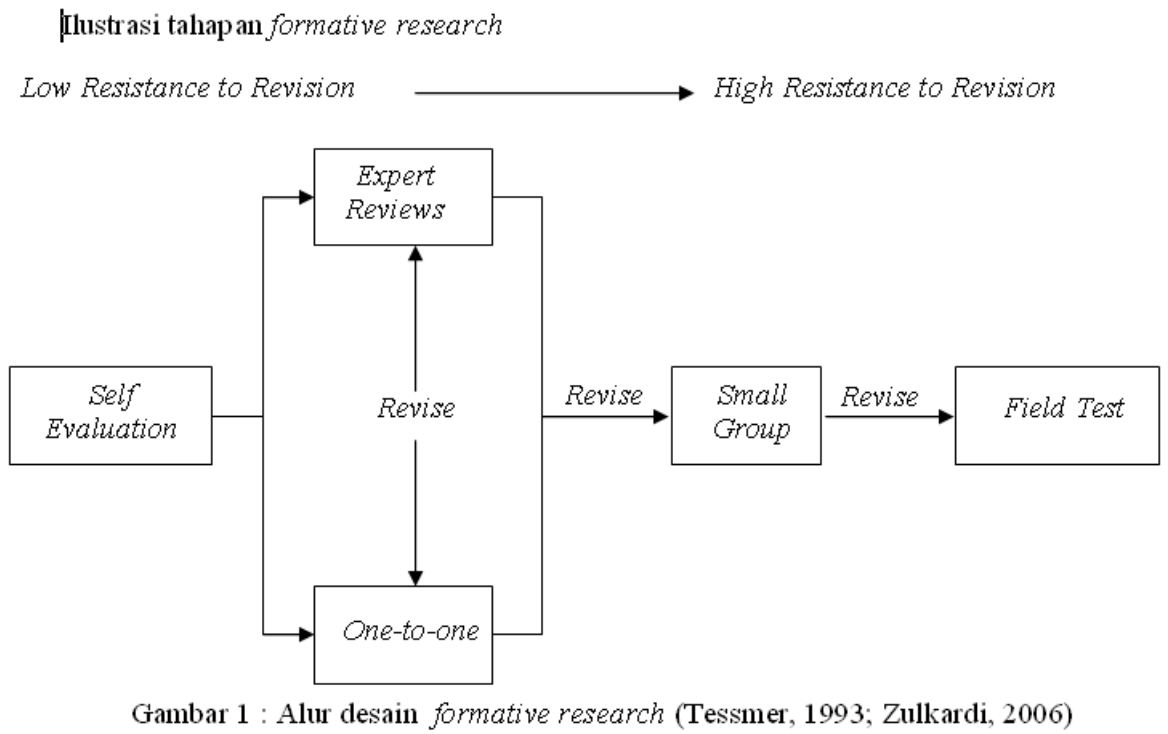

As multi-year research and development, the stages of this study include:

1) Evaluative Research (Reflection)

a) Identification and formulation of attitude aspects based on the results of the seminar.

b) Research on the Use of Attitude Assessment in C-13 (Teacher's understanding of the components of attitude assessment, Engineering (Teacher's steps in attitude assessment) and Obstacles to determining values.

2) Designing Attitude Assessment Instruments (Innovations)

3) Expert Judgment instrument

4) Empirical Trials (Small scale)

5) Instrument Revision

6) Field Test

7) Implementation (Implementation) of New Instruments in C-13 in order to preserve Cultural Values and National Character.

8) Submission of Intellectual Property Rights.

For the first year as summarised in this article, here is the summary: 


\subsection{Setting}

The study was conducted in two provinces, West Nusa Tenggara and East Jawa.

\subsection{Participants}

For the first phase of this multi-year study, 283 teachers from all levels of education, Elementary Schools, Junior High Schools, and Senior High Schools were involved.

\subsubsection{Instruments}

Questionnaire (Likert Scale) and interview

\subsection{Procedures}

\subsubsection{Data Collection}

The participants filled out the Likert Scale questionnaire. Their responses to the four scales (Strongly Agree, Agree, Disagree and Strongly Disagree) and fill in the blanks of the semi-structured questionnaire.

The researchers also used the interview guide to explore the information related to their understanding and familiarity with the use of attitude assessment instruments in the C-13.

\subsubsection{Data Analysis}

To determine the level of understanding, here are the procedures for analysing the data collected through the questionnaire:

a. determining the Maximum Score and Minimum Score

b. calculating the highest and the lowest scales scores.

c. Calculate the Maximum Score $\left(\mathrm{S}_{\mathrm{Max}}\right)$, Minimum Score $\left(\mathrm{S}_{\mathrm{Min}}\right)$, Mean $(\mu)$ and Standard Deviation (SD).

d. Insert the results of the calculations into the following criteria formula:

$$
\begin{aligned}
& \mu+1 S D s / d \mu+3 S D=G O O D \\
& \mu-1 S D<\mu+1 S D=\text { FAIRLY GOOD } \\
& \mu-3 S D s / d \mu-1 S D=\text { WORSE. }
\end{aligned}
$$

To determine the level of perception, here are the procedures:

a. determining the Maximum Score and Minimum Score

b. based on the number of items statement, the highest and lowest scale scores.

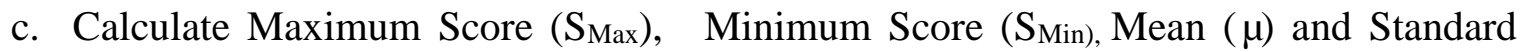
Deviation (SD).

d. To determine the level of perception, the following criteria were used: 


$$
\begin{aligned}
& \mu+1 S D \text { s } / d \mu+3 S D=\text { POSITIVE/GOOD } \\
& \mu-1 S D<\mu+1 S D=\text { POSITIVE ENOUGH/FAIRLY GOOD } \\
& \mu-3 S D \text { S/d } \mu-1 S D=\text { NEGATIVE/WORSE. }
\end{aligned}
$$

The interview results were analysed with Qualitative Iterative (Yin, 2011) \& Miles \& Huberman (1994).

\section{Results}

The results of this research summarise the answers to the research problem as formulated as follows:

4.1 Components and Aspects of Attitudes Which Are the Focus of Attitude Assessment Appropriate with the Philosophy or Demands of $C-13$

After the data were identified and classified collected through questionnaires and interviews involving 283 teachers from Sumbawa island (Bima Municipality and Kabupaten Dompu) of Sumbawa island West Nusa Tenggara; Lombok island (East Lombok Regency, Central Lombok Regency, West Lombok Regency, North Lombok Regency, and Mataram City) of West Nusa Tenggara, and Java Island (Jember City, Surabaya City, and Madura), there are 3 types of attitude assessment instruments used by the teachers, namely Observation (70\%), Interviews $(25 \%)$, and Portfolio (5\%). So, the main instrument used is observation, using various procedures. Some procedures applied by the teachers will be described in the next section.

\subsection{Teachers' Understanding of Attitude Assessment Procedures in C-13}

The questionnaire used in this study uses a scale of 4, Strongly Agree (4), Agree (3), Disagree (2), and Strongly Disagree (1). In the questionnaire, there are 11 statement items to measure the teachers' understanding of the concepts and substances of attitude assessment applied in C-13.

As the first step, determining the Maximum Score and Minimum Score based on the number of items of the statement, the highest and the lowest scales scores, and the number of informants.

$$
\begin{aligned}
& \text { Maximum Score }\left(S_{\text {Max }}\right)=11 \text { x } 4=44 \text { x } 283=12,452 \\
& \text { Minimum Score }\left(S_{\text {Min }}\right)=11 \text { x } 1=11 \times 283=3,113 . \\
& \text { Then, calculating Mean }(\mu) \text { and Standard Deviation }(S D) \text {. } \\
& \text { Mean }(\mu)=1 / 2\left(S_{\text {Max }}+S_{\text {Min }}\right) \\
& =1 / 2(12,452+3,113) \\
& =1 / 2(15,565)
\end{aligned}
$$$$
\text { Minimum Score }\left(\mathrm{S}_{\mathrm{Min}}\right) \quad=11 \times 1=11 \times 283=3,113 \text {. }
$$ 
$=7,782.5$.

Standard Deviation $(\mathrm{SD})=1 / 2\left(\mathrm{~S}_{\mathrm{Max}}-\mathrm{S}_{\mathrm{Min}}\right)$

$=1 / 2(12,452-3,113)$

$=1 / 2(9,339)$

$=4,669.5$.

To determine the level of understanding, the following criteria were used:

$\mu+1 S D s / d \mu+3 S D=G O O D$

$7,782.5+1(4,669.5) \mathrm{s} / \mathrm{d} 7,782.5+3(4,669.5)$

12,452 s/d 21,791.

$\mu-1 S D<\mu+1 S D=F A I R L Y G O O D$

$7,782.5-1(4,669.5)<7,782.5+1(4,669.5)$

$3,113<12,452$.

$\mu-3 S D s / d \mu-1 S D=W O R S E$

$7,782.5-3(4,669.5) \mathrm{s} / \mathrm{d} 7,782.5-1(4,669.5)$

$-6.226 \mathrm{~s} / \mathrm{d} 3.113$.

Of the 283 informants, the summary of the answers:

$\begin{array}{lcc}\text { Strongly Agree } & \text { (4) } & 575=2,296 \\ \text { Agree } & \text { (3) } & 2,408=7,224 \\ \text { Disagree } & \text { (2) } & 124=248 \\ \text { Strongly Disagree } & \text { (1) } & 0=0\end{array}$

9,768 .

Thus, the teachers' understanding of the attitude assessment in C-13 is at 'Fairly

Good'.

\subsection{The Teachers' Perception of the Component of Attitude Assessment in C-13}

The questionnaire used in this study contains 4 scales, namely Strongly Agree (4), Agree (3), Disagree (2), and Strongly Disagree (1). In the questionnaire, there are 9 (nine) statements to determine the teachers' perceptions of the concepts and substance of attitude assessment applied in C-13.

As a first step, determining the Maximum Score and Minimum Score based on the number of items statement, the highest and lowest scale scores, and the number of informants. 
Maximum Score $\left(\mathrm{S}_{\mathrm{Max}}\right)=9 \times 4=36 \times 283=10,188$

Minimum Score $\left(\mathrm{S}_{\mathrm{Min}}\right) \quad=9 \times 1=9 \times 283=2,547$.

Then, calculating Mean $(\mu)$ and Standard Deviation (SD).

$$
\begin{aligned}
& \text { Mean }(\mu)=1 / 2\left(S_{\text {Max }}+S_{\text {Min }}\right) \\
& =1 / 2(10,188+2,547) \\
& =1 / 2(12.735) \\
& =6,367.5 .
\end{aligned}
$$

Standard Deviation $(\mathrm{SD})=1 / 2\left(\mathrm{~S}_{\mathrm{Max}}-\mathrm{S}_{\mathrm{Min}}\right)$

$=1 / 2(10,188-2,547)$

$=1 / 2(7,641)$

$=3,820.5$.

To determine the level of perception, the following criteria were used:

$\mu+1 S D$ s $/ d \mu+3 S D=$ POSITIVE/GOOD

$6,367.5+1(3,820.5) \mathrm{s} / \mathrm{d} 6,367.5+3(3,820.5)$

10,188 s/d 17,829.

$\mu-1 S D<\mu+1 S D=$ POSITIVE ENOUGH/FAIRLYGOOD

$6,367.5-1(3,820.5)<6,367.5+1(3,820.5)$

$2,547<10,188$.

$\mu-3 S D$ s/d $\mu-1 S D=$ NEGATIVE/WORSE

$6,367.5-3(3,820.5)$ s/d $6,367.5-1(3,820.5)$

$-5,094 \mathrm{~s} / \mathrm{d} 2,547$.

Of the 283 informants, the answers:

Strongly Agree

(4) $308=1,232$

Agree

(3) $\quad 1,974=5,922$

Disgaree

(2) $224=448$

Strongly Disagree

(1) $\quad 0=0$

7,602 . 
Thus, teachers' understanding of the attitude assessment in C-13 is at 'POSITIVE ENOUGH/FAIRLY GOOD'.

\subsection{Procedure for Attitude Assessment Conducted by the Teachers}

The attitude assessment procedure includes the instrument, what is assessed when it is done and how to do the assessment. The instruments of the attitude assessment often used by the teachers include the Attitude Assessment Rubric, the Instrument for Self-Assessment / Questioning, Questions and Answers, Group Tasks, Observation, Journal Filling, and Notes. The aspects assessed include responsibility, objectivity, honesty, discipline, politeness, cooperation, learning readiness, utilization of learning outcomes and behavior change.

Regarding time, attitude assessment is carried out when teaching and learning activities take place and for one semester. Some assessment procedures applied by teachers are as follows:

a) Assessing honesty first then followed by an assessment of responsibility.

b) Grouping students, interviewing and concluding.

c) Forming groups, giving group assignments, then assessing compactness, activeness, innocence, responsibility, and honesty.

d) Recording behavior based on indicators and the time of occurrence for one semester. At the end of the semester, the teachers summarize the development of student attitudes and then processes them.

e) Observing student preparation, completeness of learning tools, recording abilities and results achieved, then analyzing and determining follow-up.

\subsection{The Reason for Teachers to Use Certain Procedures in the Attitude Assessment}

The following is a summary of the reasons why the teachers use certain attitude assessment instruments.

\subsubsection{Observation}

Observation is suitable for assessing ways of life inside and outside the classroom, behavior in preparation for learning and politeness, discipline, honesty, responsibility, completion of tasks, collaboration, student activities in a more objective self-assessment.

\subsubsection{Interview}

Effective interviews to find out directly information about how students are assessed

\subsection{Obstacles Experienced by Educators in Determining Attitude Values}

Obstacle or difficulties experienced by the teachers in measuring attitudinal values are:

a) Attitude assessment needs long time to do and involves many aspects of attitude that must be assessed and sustained. 
b) Overlapping data due to the excessive items and students and each student must be assessed continuously by focusing on many aspects.

c) It is difficult to understand the concept of C-13 attitude assessment which is so complicated and broad in its aspects.

d) The variety of attitude assessment formats and the difficulty of making and using the attitude assessment format.

e) It is difficult for teachers to assess honesty, among other things, because there are often frequent complaints.

f) There are so many students who are not serious about doing the task, so it is difficult to track the attitude aspects observed in students.

4.7 Efforts Which Have Been Done by Teachers to Solve the Difficulties in Attitude Assessment

Some of the efforts made by teachers to solve difficulties in applying attitude assessment include:

a) Doing an attitude assessment task by collecting data on accurate attitudes, including spiritual and moral attitudes.

b) Assigning assignments as often as possible and providing additional guidance, especially for the students whose behavior and attitudes are classified as negative.

c) Approaching and interacting more intensely with the students and their parents.

d) Giving rewards to the emergence of a positive attitude.

e) Improving mental preparation and student learning readiness.

f) Sharing ideas with other teachers dealing with attitude assessment.

g) Informing the importance of positive behavior and attitudes.

\section{Discussion}

Affective Assessment is an important assessment component that teachers must undertake Rabiudin et al. (2018). From 10 aspects of attitude mentioned in the attitude assessment rubric of the $\mathrm{C}-13$, those relevant with the $\mathrm{C}-13$ philosophy and objectives include honesty, responsibility, tolerance, discipline, cooperation, peace, and politeness. This is in line with the ones determined by the Ministry of Education and Culture of the Republic of Indonesia, namely Honesty, Discipline, Responsibility, Tolerance, Mutual Cooperation, Politeness and Self-confidence (Ministry of National Education, 2017).

The dominant attitude assessment instruments used by the teachers are Observation and Interview. The choice of this instrument is relevant to the demands of C-13 to use observation 
as the main instrument of attitude assessment. The reason for using certain attitude assessment instruments is based on their compatibility, practicality, and effectiveness in data collection and attitude assessment, which will be beneficial for the development of the character of the generations. This reasoning is consistent with Arifuddin's (2015) statement that the need for innovative attitude assessment instruments is very urgent. Obviously, day by day, the degradation of moral and character of the generation are transparently evident in front of us.

Teachers' perceptions of the attitude assessment component in C-13 are in the category 'Fairly Positive or Fairly Good'. This finding is relevant to the results of the monitoring and evaluation implementation of C-13 conducted by Surapi, et al. (2014) indicating that the teachers' perception of the implementation of the C-13 is at the 'Good Enough' level. The teachers find it difficult to asses the too many indicators of each aspect of the attitude assessment. The obstacle, for example, when doing an observation to every student as an instrument for attitude assessment, the teachers must also focus on the teaching process and the delivery of the material to the students simultaneously (Setyowati et al., 2014).

Teachers' understanding of attitude assessment procedures in C-13 is in the category of 'Sufficiently Understanding'. This finding is relevant to the results of the monitoring and evaluation of the implementation of the C-13 in the West Nusa Tenggara Province conducted which shows that the teachers in West Nusa Tenggara are less competent in applying authentic assessment and attitude assessment in C-13 (Surapi et al., 2014). Quite a lot shows that there are obstacles and problems in the implementation of authentic assessments, especially attitudes assessment. This is in relevant with Ningsih's (2012) statement that teachers also experience obstacles in making assessment or scoring decisions. Such conditions provide opportunities for unreliable, unaccountable and non-objective assessment results that are not expected from educators who are required to have high integrity.

The majority of teachers still have difficulties in understanding how to assess C-13 (Rusilowati, 2013). Difficulties were found in implementing attitude assessments in the Curriculum of School Levels and C-13 (Putra, 2014). For example, in assessing writing skills in Indonesian language, it indicates that teachers' mastery of an authentic assessment system. In addition, the low level of understanding is related to the usefulness of the analysis of process evaluation results, collection of the value of process and learning outcomes, authentic assessment, and description of reports not yet fully understood by educators (Suharji, 2014). Teacher's understanding of attitude assessment rubrics is a problem. Low understanding cannot be separated from the substance and characteristics of authentic research/attitude. In practice, there is an opportunity to engineer values in attitude assessment. This can happen if there is no standard reference or rubric available. Good students and bad students are the standard difference in values, while other values are just the general standard (Rosalinda 2016).

The obstacle faced by Civics teachers in the 2006 Curriculum assessment is that there is no clear benchmark in assessing attitudes, which is an obstacle in developing an attitude assessment instrument (Rahmawati n.d.). The learning evaluation obstacle faced by the 
teachers in the implementation of $\mathrm{C}-13$ is related to the complexity of the assessment format. It consists of three aspects assessed, namely the assessment of attitudes, knowledge, and skills. The primary obstacle to the understanding of the affective assessment is the absence of socialization of the assessment guidelines (Taruh \& Mursalin, 2018). The other obstacles experienced by the teachers in the application of attitude assessments are related to the amount of time needed, the coverage of aspects or indicators of attitude that are too broad and complex, continuous assessment for each student, lack of understanding of concepts, the variety of formats, difficulty in measuring some aspects of attitude. This is relevant to the research of Setyowati et al. (2014) which shows that the teachers found it difficult to use too many indicators targetted in the rubric, especially in the aspect of attitude assessment. Absari, et al. (2015) also state that this difficulty is caused by the complexity of the authentic assessments which requires a balance of assessment of knowledge, attitudes, and skills.

The efforts made by the teachers to solve the problems of attitude assessment difficulties can be done through collecting data about attitudes through assignments, sharing ideas with other teachers, providing additional guidance to students having problems, intense interactions with the students and their parents, giving rewards when positive attitudes arise and preparing students' mental before learning. Based on these efforts, the teachers do not have an adequate basis for finding and developing the solutions to the obstacles in the implementation of the complex attitude assessments.

\section{Conclusion}

It shows: 1) Of the 10 aspects of attitude mentined in the $\mathrm{C}-13$ attitude assessment rubric, which are relevant with the $\mathrm{C}-13$ philosophy and objectives, namely honesty, responsibility, tolerance, discipline, cooperation, peace, and courtesy; 2) Teachers' perceptions of the attitude assessment component in C-13 are in the category 'Fairly Positive/Fairly Good'; 3) Teachers' understanding of attitude assessment procedures in C-13 is in the 'Fairly Good' category; 4) The dominant attitude assessment instrument used by the teachers are Observation and Interview; 5) The reason for using certain attitude assessment instruments is based on suitability, practicality, and effectiveness in data collection and attitude assessment; 6) Obstacles experienced by the teachers in applying the attitude assessment are related to the amount of time needed, the too broad scope of the attitude aspects, continuous assessment for each student, lack of understanding of concepts, variety of formats, difficulty in measuring several aspects of attitude; and 7) The efforts made by the teachers to solve the problem of attitude assessment difficulties, namely collecting data about attitudes through assignments, sharing ideas with other teachers, providing additional guidance to students having problems, intense interactions with the students and their parents, giving rewards when positive attitudes emerge and preparing students mentally before learning. 


\section{Macrothink}

\section{References}

Absari, I. G. A. K. L., Sudiana, N., \& Wendra, I. W. (2015). Authentic assessment applied by the Indonesian language teachers in the writing ability of the Seventh Grade Students of Junior Haigh School 1 Singaraja. e-Journal Universitas Pendidikan Ganesha Jurusan Pendidikan Bahasa dan Sastra Indonesia, 3(1).

Agih, A. A. (2017). Integrating elements of the affective domain in teaching, assessment and grading of students' performance for effective learning. Journal of Emerging Trends in Educational Research and Policy Studies, 8(4), 232-236.

Arifuddin, A. (2015). Character education in Indonesia: Who are the educators? Who are learners? When is assessment span? National Seminar Proceeding on Charater Education for the Better Indonesia held in 2014 at STIKP Hamzanwadi Pancor East Lombok. Pages 1-11. Mataram: FKIP University of Mataram Press.

Birbeck, D. (2009). Graduate qualities and the affective domain: New Horizons to explore. Adelaide University of South Australia.

Colby, A., \& Sulliva, W.M. (2009). Rethinking undergraduate busijess education. The Carnegie Foundation for the Advancement of Teaching. Standofrd: Jossey-Bass.

Elfindri. (2012). Character education: Framework, Method, and Application in Education and Professionalism. Jakarta: Baduose Media.

Gerlaugh, K., Thompson, L., Boylan, H., \& Davis, H. (2007). National study of developmental education II: Baseline data for community colleges. Research in Developmental Education, 20(4), 1-4.

Gronlund, N. E., \& Brookhart, S. M. (2009). Writing instructional objectives (8th ed.). Upper Saddle River, NJ: Pearson Education.

Hambali. (2015). Students' reaction towards nation characters education and the impacts on the practice of nationalist characters. Journal of Applied Science, 15(9), 1167-1175. https://doi.org/10.3923/jas.2015.1167.1175

Keblowska, M. (2012). The Place of Affect in Second Language Acquisition. In Pawlak, Mirostaw (Ed.), Second Language Learning and Teaching: New Perspective on Individual Differences in Language Learning and Teaching (pg. 157-167). New York: Springer. https://doi.org/10.1007/978-3-642-20850-8_10

Koesoema A. D. (2012). Character education: Unified and holistic. Yogyakarta: Kanisius.

Lickona, T. (2012). Education for character building. Jakarta: Bumi Aksara.

Mardapi, D. (2012). Measurement of educational evaluation \& evaluation. Yogyakarta: Nuhamedika.

Mustari, M. (2014). Character Value: Reflection for education. Jakarta: Rajagrafindo Persada. 
Ningsih, N. (2012). Teachers' Hindrances in the implementation of assessment at SMAN 1 Sanden. Jurnal Citizenship, 1(2), 123-132.

Petrosyan, Silva, \& Khachatryan Serob et al. (2005). Integrated Social Studies Instruction, Curriculum Design and Models: An Educator's Handbook. Yerevan: Bureau of Educational \& Cultural Affairs.

Rabiudin, Taruh, E., \& Mursalin. (2018). Development of Authentic Affective Assessment Instrument in High School Physics Learning. 2nd International Conference on Statistics, Mathematics, Teaching, and Research IOP Publishing. Journal of Physics: Conf. Series 1028 (2018) 012201 https://doi.org/10.1088/1742-6596/1028/1/012201

Rahmawati, A. L. (2015). A Comparative study on the implemantation of the assessment of Citizenship Course in the 2006 and the 2013 Curriculums at the Junior High Schools in Wonosori Gunungkidul Regency. Unpublished thesis. Yogyakarta: Fakultas Ilmu Sosial.

Rosalinda, N. (2016). The implementation of the Curriculum and its barriers. Retrieved on February, 4, 2016 from http://www.kompasiana.com/naniekonomi/pelaksanaan-kurikulum-2013-dan-kendala_5 $52 \mathrm{fccc} 86 \mathrm{ea} 834183 \mathrm{f} 8 \mathrm{~b} 45 \mathrm{f} 6$

Rusilowati, A. (2013). Kurikulum 2013, 87 persen guru kesulitan dalam cara penilaian. Dari: http://unnes.ac.id/berita/87-persen-guru-kesulitan-soal-penilaian-kurikulum-2013/Diund uh 4-2-2016. Sabtu, 14 Desember 2013 | 16:17 WIB.

Saxon, D. P., Levine-Brown, P., \& Boylan, H. R. (2008). Affective assessment for developmental students, part 1. Research in Developmental Education, 22(1), 1-4.

Setyowati, Siswandari, \& Octoria. (2014). The Study on Teachers' pedagogical Competency in Accounting Subjects of the State Vocational School No. 6 Surakarta in the implementation of the 2013 Curriculum. Jupe UNS, 2(3), 312-322.

Suharji. (2014). Evaluation of the implementation of assessment standard in Elementary Schools in Sleman Regency of Yogyakarta Province. Yogyakarta: Department of Education and Sport.

Sunarpi, Amiruddin, Syafruddin, Sukadi, Setiadi, D., Wadi, H., Arifuddin \& Hakim, A. (2014). The Report of Monitoring and Evaluation the Implementation of the 2013 Curriculum in West Nusa Tenggara Province. Unpublished Research Report. Mataram: Research Centre University of Mataram.

Taruh, E., \& Mursalin. (2018). Development of Authentic Assesment Tools in Physics Science Learning. 2nd International Conference on Statistics, Mathematics, Teaching, and Research IOP Publishing IOP Conf. Series $1028 \quad$ (2018) 012200. https://doi.org/10.1088/1742-6596/1028/1/012200

Tressmer, M. (1998). Planning and conducting formative evaluations. Philadelphia: Kogan Page. 


\section{Macrothink}

\section{Copyright Disclaimer}

Copyright for this article is retained by the author(s), with first publication rights granted to the journal.

This is an open-access article distributed under the terms and conditions of the Creative Commons Attribution license (http://creativecommons.org/licenses/by/3.0/). 